\title{
Quantitative Geomorphology Related to Active Tectonics in The Cilayu Watershed, West Java Province, Indonesia
}

\author{
Mirza Muhajir ${ }^{1}$; Emi Sukiyah² ${ }^{2}$ Reza Mohamad Ganjar Gani ${ }^{3}$
}

Geological Engineering Program, Faculty of Geological Engineering, UniversitasPadjadjaran, Jl. Raya Bandung-Sumedang KM.21, Sumedang, 45363, Indonesia ${ }^{1}$

Geomorphology \& Remote sensing Laboratory, Faculty of Geological Engineering, UniversitasPadjadjaran, Jl. Raya Bandung-Sumedang KM.21, Sumedang, 45363, Indonesia ${ }^{2}$

Stratigraphy Laboratory, Faculty of Geological Engineering, UniversitasPadjadjaran, Jl. Raya BandungSumedang KM.21, Sumedang, 45363, Indonesia ${ }^{3}$

mirza16001@mail.unpad.ac.id ${ }^{1}$; emi.sukiyah@unpad.ac.id ${ }^{2}$; reza.mohammad@unpad.ac.id ${ }^{3}$

DOI $10.26821 /$ IJSHRE.8.7.2020.8706>

\begin{abstract}
The Cilayu watershed is selected to analyze and predict relative tectonic activity based on geomorphic indices. This area is prone earthquakes originating from subduction zones at sea and active faults on land. To assess tectonic activity in the area, we analyzed fives geomorphic indices: the mountain front sinuosity index (Smf), valley floor width-to-height ratio (Vf), drainage basin asymmetry factor (Af), drainage basin shape $(B s)$, and hypsometric integral (Hi). Then based on the index of active tectonics (IAT) values calculated by the average of five geomorphic indices, relative tectonic activity levels revealed. The research area proved to be an active tectonic area, confirmed by values of $A F, B s, V f, S m f$, and $\mathrm{Hi}$. Value of $A F$ 24.83 - 67.77, Bs 0.97 - 3.81, Vf 0.17 - 7.03, Smf $1.16-2.54$, and Hi 0.31 - 0.61 showing that some area in Cilayu watershed has been affected by active tectonics. The drainage patterns that can be recognized are trellis, parallel, and rectangular. On the other hand, these drainage patterns reflect the control of geological structures. The study area was divided into three parts: Class 1 (very high tectonic activity, $1.78 \%$ in area); Class 2 (high, 7.03\%); Class 3 (moderate, 30.68\%), and Class 4
\end{abstract}

(10w, 9.69\%). The results are consistent with field observations on landforms and geology.

Keywords:Morphotectonic;

Geomorphic

Indices; Cilayu watershed; IAT.

\section{INTRODUCTION}

In areas affected by moderate tectonic deformation rates, geomorphology and geological data provide some of the best information to support and characterize active tectonics [1],[2], [3].

One exciting area to study to characterize the active tectonic effect is the Cilayu watershed, West Java. This area is one of the earthquake-prone areas originating from subduction zones at sea and active faults on land. Therefore it is crucial to analyze the activity level of the Cilayu watershed from the geomorphological study.

To characterize the geomorphic features of a landscape, quantitative geomorphic analyses (morphotectonics) conducted using geomorphic indices, which help to assess the relative level of tectonic activity in an area [4], [5], [6], [7], [8].

Morphotectonics can express a roman topographic view that can use as an indicator of the style, strength, and average tectonic movement. In other words, the tectonic activity of a location known as

Mirza Muhajir ; Emi Sukiyah ; Reza Mohamad Ganjar Gani, Vol 8 Issue 7, pp 47-58, July 2020 
Volume 8 Issue 7 July 2020

supported by qualitative spatial data and geomorphology. With the method used in this study, it expected that the results would be a general picture of tectonic activity in the research area with a fast and efficient process.

The Cilayu upstream to downstream distinguished in several morphographic units such as mountains, hills, valleys, and plains [9]. The different slope affects the drainage pattern in the Cilayu watershed. The drainage patterns that can be recognized are trellis, parallel, and rectangular. All of the drainage patterns reflect the control of geological structures.

According to [10] and [11], the study area composed of 7 rocks formations (Fig.1). In general, these formations consist of tertiary sedimentary rocks (Tmk, Tmpb), which form tuff sandstone, pumice tuff, claystone, conglomerate, lignite, and breccia. Volcanic rocks that form well-cemented breccia (Tomj), lavas, tuff, and tuff breccia (QTv, Tpv), alternation of lavas breccia and tuff, pyroxene-andesitic and hornblende-andesitic composition (Qwb). Intrusive rocks which form pyroxene andesitic (pa) and quartz diorite (Tmi (d)).

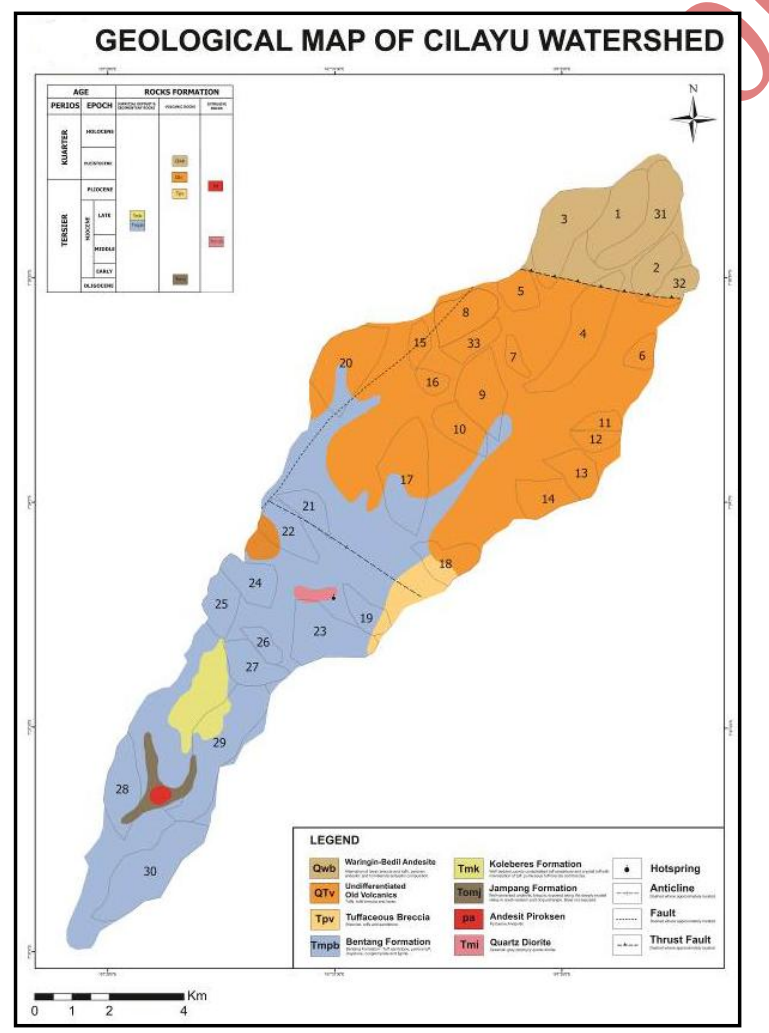

Fig 1: Regional geology of the study area is showing the distribution of lithology from different rocks formations in Cilayu Watershed (Modified from [10] and [11].

\section{MATERIAL AND METHOD}

This study aims to identify the index of active tectonics (IAT) based on quantitative geomorphology analysis. Parameterssubjects in this research of the Cilayu watershed, which consists of drainage basin asymmetry $(A F)$, hypsometricintegral $(H i)$, valley floor width-valley height ratio $(V f)$, drainage basin shape $(B s)$, and mountainfront-sinuosity $(S m f)$.

The methodology relies on the identification and interpretation of topographic map (Topographic map of Indonesia), Geological Map [10,11], Digital Elevation Model (DEM) of Cilayu watershed. The data from DEMNAS in the laboratory using computer program supporting Geographical Information System (GIS) software and field observation to Cilayu watershed.

\subsection{Geomorphic Indices}

Geomorphic indices useful for studying active tectonics include drainage basin asymmetry $(A F)$, hypsometric-integral $(\mathrm{Hi})$, valley floor widthvalley height ratio $(V f)$, drainage basin shape $(B s)$, and mountain-front-sinuosity index (Smf) [7].

The geomorphic indices of active tectonics calculated by using a topographic map and DEM. On the other hand, thearea divided into 33 subwatershed, and for each one, the above indices calculated. All of the indices were combined to obtain the index of active tectonics (IAT) [13]. Therefore, sub-basins can compare together. 
Volume 8 Issue 7 July 2020

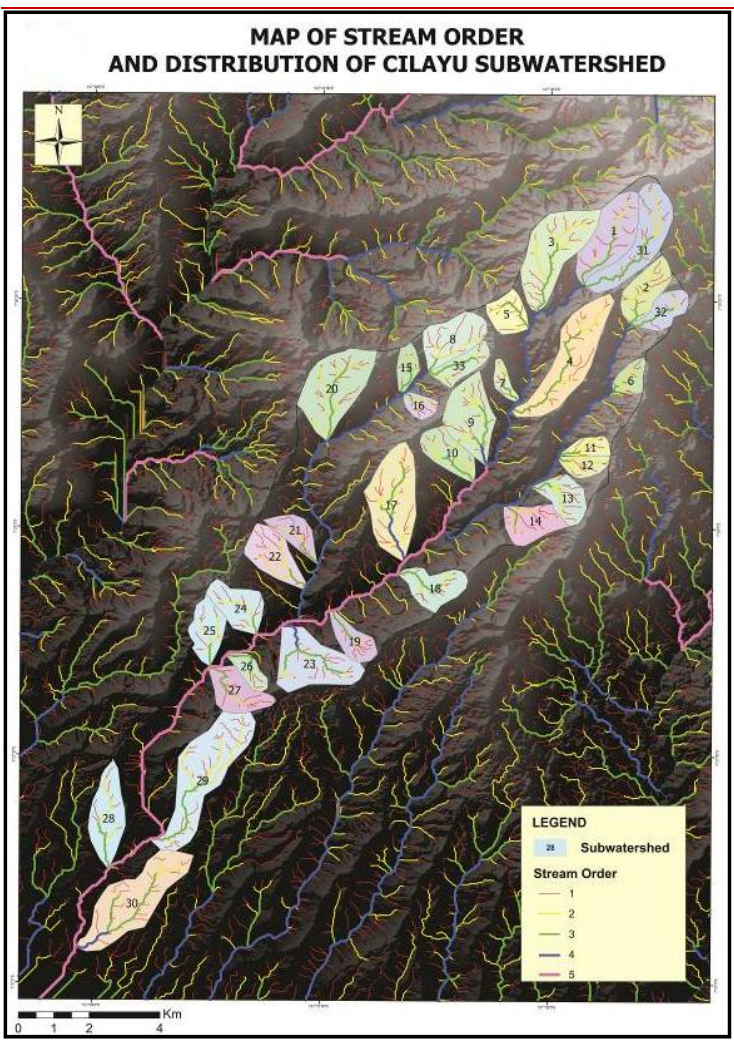

Fig 2: Stream order map and distribution of Cilayu sub-watershed.

\subsubsection{Asymmetry Factor $(A F)$}

The asymmetric factor $(A F)$ can be used to evaluate tectonic tilting [7], [12]. $A F$ is defined as:

$$
A F=100(A r / A t)
$$

$A_{r}$ is the area of a part of the watershed on the right of the master stream (looking downstream), and $A_{t}$ is the total area of the watershed. Both $A_{r}$ and $A_{t}$ measured in GIS Software. If $A F>50$, it indicates that the tilting direction of the basin is to the left (from downstream point of view). However, if $A F<$ 50 , it indicates that the tilting direction is to the right side of the basin [7]. $A F$ values were grouped into three classes: $1(A F \geq 65$ or $A F<35) ; 2$ (35 $\leq$ $A F<43$ or $57 \leq A F<65)$, and $3(43 \leq A F<57)$ [13]. (Table I).

Then, to show the extent to which the asymmetry develops in a watershed, the $A F$ value is expressed as an absolute value minus 50, added with arrows indicating the direction of the asymmetry [14].Then $A F$ absolute values were grouped into four classes: $A F<5$ (symmetric basins), $A F=5-10$ (gently asymmetric basins), $A F=10-15$ (moderately asymmetric basins), and $A F>15$ (strongly asymmetric basins) [14].

\subsubsection{Basin Shape Index (Bs)}

The Basin shape index $(B s)$ is a comparison between basin length $(B l)$ or watershed length measured from the highest point with basin width $(B w)$ axis or watershed width measured from the widest [15].Relatively young drainage basins in active tectonic areas tend to be elongated in shape, normal to the topographic slope of a mountain [17], [18].Bs value in more active tectonics will be elongated and will become circular after the tectonic process has slowed or stopped. The value of $B s$ calculated using this question:

$$
B s=B l / B w(2)
$$

$B s$ values computed using a topographic map, and DEM then grouped into three classes; class $1(B s \geq$ $4)$, class $2(3 \leq B s<4)$, and class $3(B s \leq 3)$ [13]. (Table 1).

\subsubsection{Valley floor width-valley height ratio (Vf)}

The valley width and height ratio $(V f)$ is one of the calculations that can characterize the existence of an active fault. Calculations that can use to determine the occurrence of uplift that occurs can use the ratio between the width of the valley floor with the height of the valley, better known as $V f$ [16], formulated as follows:

$$
\boldsymbol{V} f=2 \boldsymbol{V} \boldsymbol{f} \boldsymbol{w} /[(\boldsymbol{E l d}-\boldsymbol{E s c})+(\boldsymbol{E r d}-\boldsymbol{E s c})]
$$

$V f$ wis the width of the valley floor. Eld, Erd, and Escare the river elevations - left, right, and center and divided valleys lead to downstream and the stream channel, respectively. $V f$ was calculated for the main valleys in the study area using crosssections drawn from the DEM and the digitized 1:25,000 topographic map. Then $V f$ was classified into three classes: $1(V f \leq 0.5) ; 2(0.5 \leq$ $V f<1.0)$ and $3(V f \geq 1[13]($ Table 1$)$.

\subsubsection{Mountain-front sinuosity index (Smf)}

[16] and [18] define the mountain-front-sinuosity index (Smf) as a comparison between the planimetric length of a mountain front along the mountain-piedmont junction ( $L m f$ ) and the straightline length of the front $(L s)$, expressed equation as follows:

$$
S m f=L m f / L s
$$

The values of Smf calculated for 17 mountain fronts using $L m f$ and $L s$ values measured from DEM and a topographic map and divided into three 
Volume 8 Issue 7 July 2020

classes: $1(\operatorname{Smf}<1.1), 2(1.1 \leq S m f<1.5)$, and 3 $(S m f \geq 1.5)$ [13] (Table 1).

\subsubsection{Hypsometric Integral (Hi)}

The hypsometric integral $(\mathrm{Hi})$ describes the relative distribution of elevation in a given area of a landscape, particularly a drainage basin [19].Hypsometric Integral is an area located on the curve of the hypsometry. Hypsometric Integral is giving the symbol $\mathrm{Hi}$ calculated in the watershed using Equation 5.

\section{$H i=($ avrg.elev - min.elv $) /($ max.elv.-min.elv $)(5)$}

Using Eq. (5), we computed $\mathrm{Hi}$ for each subwatershed. Then $H i$ values were grouped into three classes to the convexity or concavity of the hypsometric curve: Class 1 with convex hypsometric curves $(H i \geq 0.5)$; Class 3 with concave hypsometric curves $(H i<0.4)$; and Class 2 with concave-convex hypsometric curves $(0.4 \leq$ $H i<0.5)$ [13] (Table 1).

\subsubsection{Index of Active Tectonics (IAT)}

This index represents a summary and average of calculated geomorphic indices used in this study. The value of $I A T$ calculated using this question:

$$
I A T=S / n
$$

Where $S$ represents the sum of geomorphic indiees, $n$ represents the number of selected indices [13]. The values of this index were grouped into four classes to define the degree of active tectonics; $1-$ very high $(1.0 \leq I A T<1.5) ; 2$-high $(1.5 \leq$ $I A T<2.0) ; 3$-moderate $(2.0 \leq I A T<2.5)$; and $4-$ low $(2.5 \leq I A T)$ [13]. The ranges of geomorphic indices related to the Index of Active Tectonics (IAT) shown in Table 1.

Table 1. The Range of Geomorphic Indices Refers To [13]

\begin{tabular}{|c|l|l|l|}
\hline \multirow{2}{*}{ Aspect } & \multicolumn{3}{|c|}{ Relative Tectonic Activity } \\
\cline { 2 - 4 } & $\begin{array}{c}\text { Class 1 } \\
\text { (High) }\end{array}$ & $\begin{array}{c}\text { Class 2 } \\
\text { (Moderate) }\end{array}$ & $\begin{array}{c}\text { Class 3 } \\
\text { (Low) }\end{array}$ \\
\hline$A F$ & $\begin{array}{c}(A f \geq 65) \text { or } \\
(A f<35)\end{array}$ & $\begin{array}{l}(35 \leq A f<43) \\
\text { or }(57 \leq A f<65)\end{array}$ & $\begin{array}{l}(43 \leq A f< \\
57)\end{array}$ \\
\hline$B s$ & $(B s \geq 4)$ & $(3 \leq B s<4)$ & $(B s \leq 3)$ \\
\hline$V f$ & $(V f \leq 0.5)$ & $(0.5 \leq V f<1.0)$ & $(V f \geq 1)$ \\
\hline$S m f$ & $(S m f<1.1)$ & $(1.1 \leq S m f<1.5)$ & $(V f \geq 1)$ \\
\hline$H i$ & $(H i \geq 0.5)$ & $(0.4 \leq H i<0.5)$ & $(H i<0.4)$ \\
\hline
\end{tabular}

\subsection{Field Observation}

The field observation aims to provide valid data related to geological structures in the study area compared with geomorphic indices calculation results. We recognize the fault scarp, ridge/valley lineament, and rockslide phenomenon as the presence of geological structures in the study area. Moreover, we conducted the measurements of joints to define the trend of the tectonic stress that occurs in the study area. The rosette diagrams inform about the fracture trend while the stereonets inform about the trend of the stress which symbolizes with $\sigma$ (Sigma).

\section{RESULT AND DISCUSSION}

\subsection{The Asymmetry Factor (AF)}

Af is close to 50 if there is no or little tilting perpendicular to the direction of the master stream. Af is significantly higher or smaller than 50 under the effects of active tectonics or substantial lithologic control [15].

The results of the calculation of $A F$ values in the study area showed $A F$ values varied from 24.83 (Sub-watershed 14) to 67.77 (Sub-watershed 9). There are 10 sub-watersheds with $A F$ values which are classified into tectonic class 1 (High): 3(67.73), 6(28.79), 9(67.77), 10(32.12), 14(24.83), 15(65.63), 18(26.85), 20(65.06), 21(28.87), and 33 (28.87). Ten sub-watersheds have $A F$ values that classified into tectonic classes 2 (Moderate), and the other 13 have $A F$ values that classified into tectonic classes 3 (Low) (Fig.3) (Table 2). 
Volume 8 Issue 7 July 2020

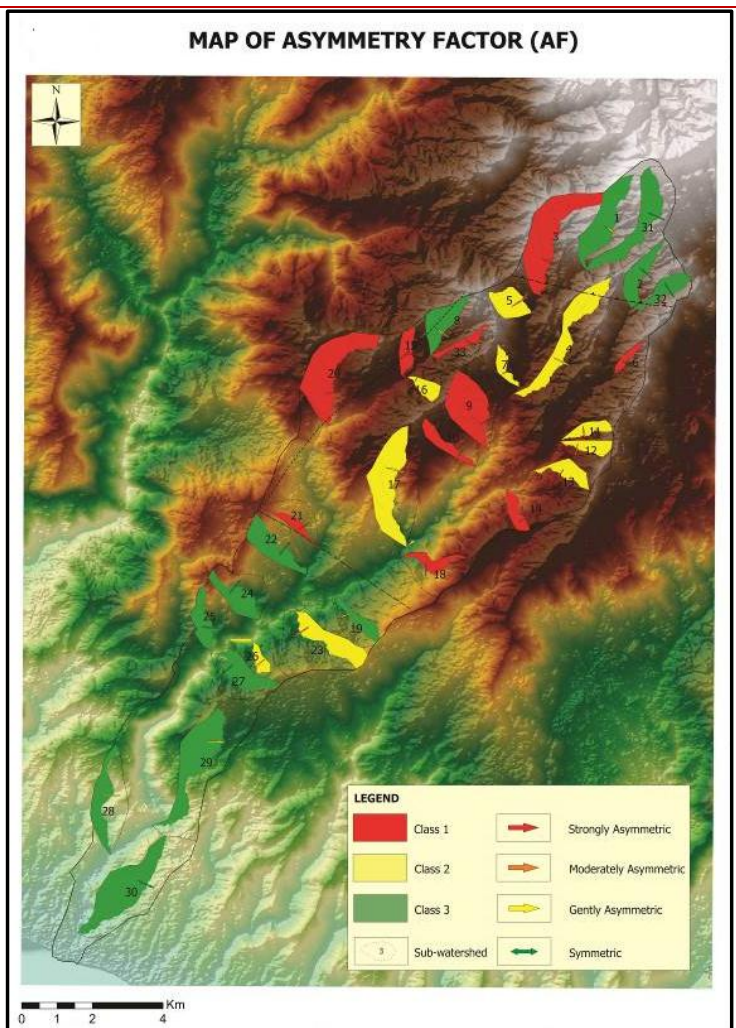

Fig3: Distribution of the Asymmetry Factor $(A F)$ class in Cilayu Watershed.

Table 2. Asymmetry Factor $(A F)$ Calculation

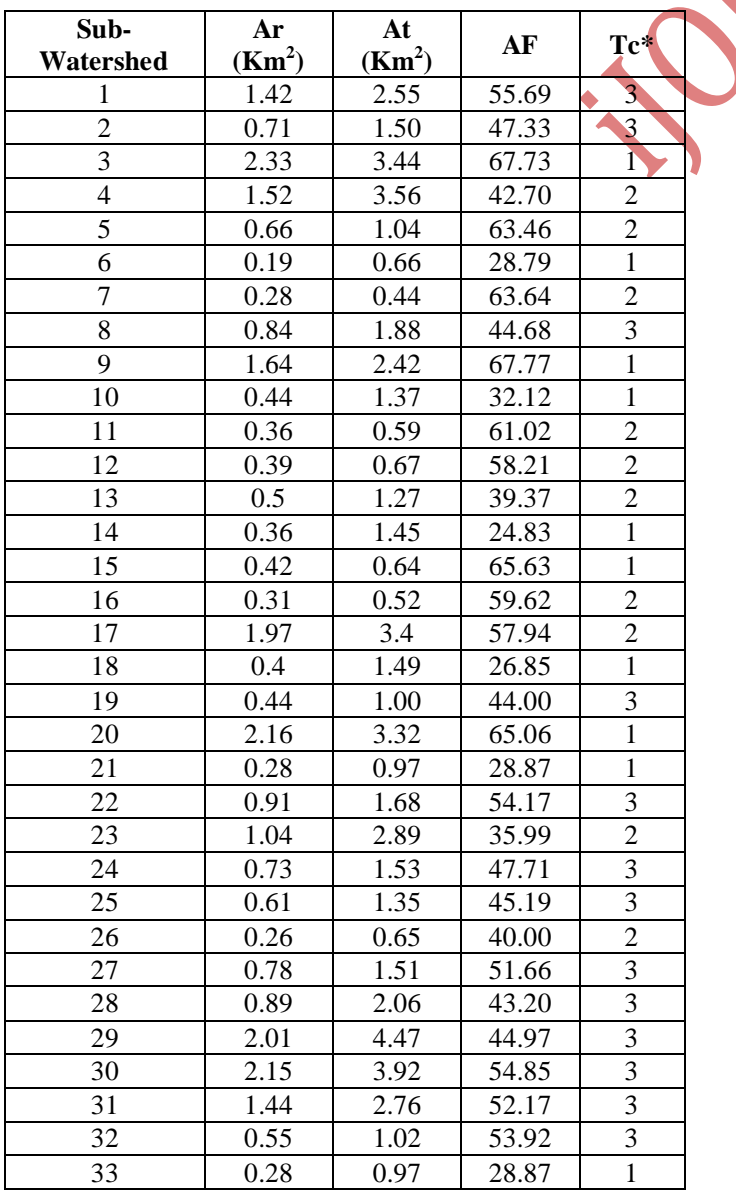

*Tc: Tectonic Class

\subsection{The f Basin Shape Index $(B s)$}

$B s$ values in the study area calculated at 33 Subwatersheds. Based on the calculation, the $B s$ value of the study area ranged from 0.97 (Sub-watershed 14) to 3.81 (Sub-watershed 4) (Tabel 3).

Table 3. Basin Shape Index (BS) Calculation

\begin{tabular}{|c|c|c|c|c|}
\hline $\begin{array}{c}\text { Sub- } \\
\text { Watershed }\end{array}$ & $\begin{array}{c}\text { Bl } \\
(\mathbf{m})\end{array}$ & $\begin{array}{l}\text { Bw } \\
(\mathbf{m})\end{array}$ & Bs & Tc* \\
\hline 1 & 2998 & 1113 & 2.69 & 3 \\
\hline 2 & 2179 & 935 & 2.33 & 3 \\
\hline 3 & 3418 & 1358 & 2.52 & 3 \\
\hline 4 & 4266 & 1121 & 3.81 & 2 \\
\hline 5 & 1178 & 1040 & 1.13 & 3 \\
\hline 6 & 1278 & 741 & 1.72 & 3 \\
\hline 7 & 1344 & 463 & 2.90 & 3 \\
\hline 8 & 2029 & 1332 & 1.52 & 3 \\
\hline 9 & 2732 & 1506 & 1.81 & 3 \\
\hline 10 & 2012 & 944 & 2.13 & 3 \\
\hline 11 & 1469 & 536 & 2.74 & 3 \\
\hline 12 & 1438 & 638 & 2.25 & 3 \\
\hline 13 & 1568 & 1188 & 1.32 & 3 \\
\hline 14 & 1430 & 1470 & 0.97 & 3 \\
\hline 15 & 1481 & 660 & 2.24 & 3 \\
\hline $16>$ & 1003 & 714 & 1.40 & 3 \\
\hline 17 & 3414 & 1461 & 2.34 & 3 \\
\hline 18 & 1903 & 1235 & 1.54 & 3 \\
\hline 19 & 1839 & 883 & 2.08 & 3 \\
\hline 20 & 2742 & 1623 & 1.69 & 3 \\
\hline 21 & 2005 & 744 & 2.69 & 3 \\
\hline 22 & 2305 & 1126 & 2.05 & 3 \\
\hline 23 & 2686 & 1694 & 1.59 & 3 \\
\hline 24 & 1944 & 1225 & 1.59 & 3 \\
\hline 25 & 2078 & 1055 & 1.97 & 3 \\
\hline 26 & 1513 & 554 & 2.73 & 3 \\
\hline 27 & 2132 & 1212 & 1.76 & 3 \\
\hline 28 & 3144 & 1044 & 3.01 & 2 \\
\hline 29 & 4602 & 1370 & 3.36 & 2 \\
\hline 30 & 4247 & 1416 & 3.00 & 2 \\
\hline 31 & 2569 & 1160 & 2.21 & 3 \\
\hline 32 & 1836 & 890 & 2.06 & 3 \\
\hline 33 & 1849 & 702 & 2.63 & 3 \\
\hline
\end{tabular}

*Tc: Tectonic Class

In Figure 4, Bs class 2 seen in Sub-watershed 4, 28, 29 , and 30 , with the presence of fault structures around Sub-watershed 4. While the other 29 Subwatershed classified as class 3 , which are spread almost evenly across the study area, in several subwatershed classes three, there are structures, namely fault, an anticline. $B s$ class 3 is estimated to be related to the tectonic process, which slows down or stops so that the shape of the watershed increasingly rounded. In general, based on $B S$ analysis, both sub-watershed based on sedimentary rocks and volcanic rocks, most of the $B s$ values are classified into tectonic class 3 . This $B s$ value shows that the tectonic process is slowing down and the erosion process tends to develop more, causing the 
ISSN-2347-9698

Volume 8 Issue 7 July 2020

shape of the watershed to become more rounded, the presence of Bs Class 2 is suspected as a result of the existence of structures in the sub-watershed.

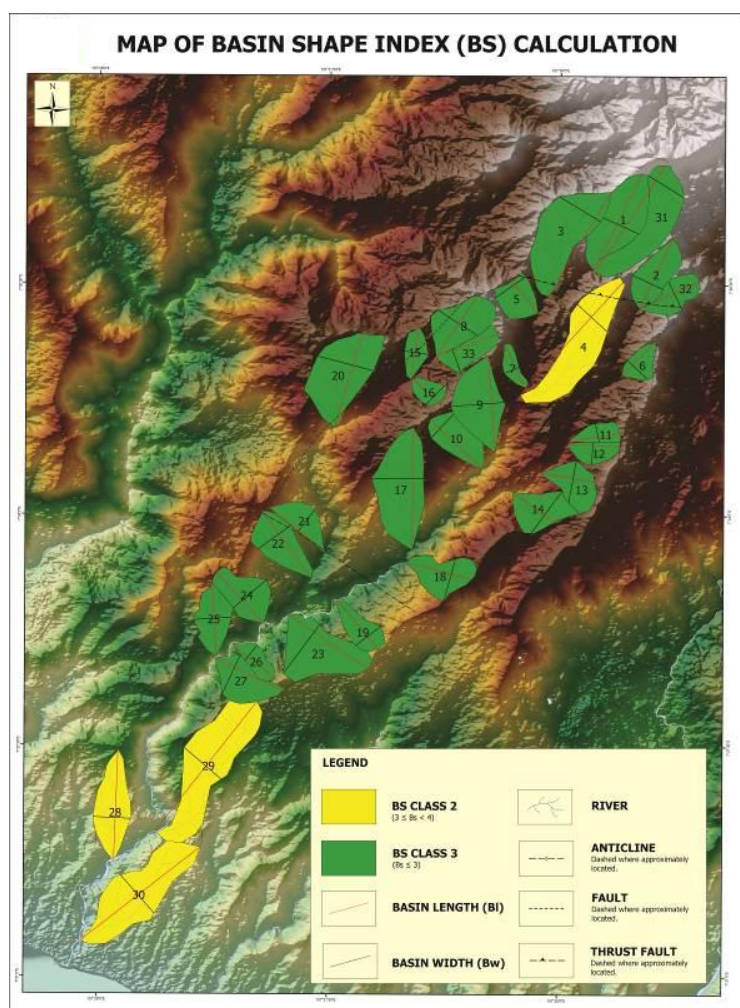

$-{ }_{-1}^{-}{ }_{4}^{\mathrm{m}}$

Fig 4:Map of Basin Shape Index (Bs) Calculation in Cilayu Watershed.

\subsection{The Valley Floor Width-Valley Height Ratio ( $V f)$}

The values of $V f$ for the study area shown in Table 4. Values of $V f$ vary-form a low of 0.17 (Number 15) to a high of 2.04 (Number 23). According to[20], V-shaped valleys with low $V$ fvalues < 1 develop in response to active uplift, and that broad U-shaped valleys with high $V f$ values $>1$ indicate significant lateral erosion, due to the stability of base level or to tectonic quiescence.

There are $15 \mathrm{Vf}$ values which are classified into tectonic class 1 (High): 1(0.47), 6(0.43), 8(0.32), $9(0.32), 11(0.35), 12(0.38), 13(0.30), 14(0.37)$, 15(0.17), 18(0.36), 19(0.36), 21(0.37), 27(0.43), 30(0.49) and 33(28.87). $11 V f$ values are classified into tectonic classes 2 (Moderate) and the other 7 $V f$ values which are classified into tectonic classes 3 (Low) (Table 4).
Table 4. Valley Floor Width-Valley Height Ratio $(V f)$ Calculation

\begin{tabular}{|c|c|c|c|c|c|c|}
\hline No & $\begin{array}{l}V f w \\
(m)\end{array}$ & $\begin{array}{l}\text { Eld } \\
\text { (m) }\end{array}$ & $\begin{array}{l}\text { Erd } \\
(m)\end{array}$ & $\begin{array}{r}E s c \\
(m)\end{array}$ & $V f$ & $T c^{*}$ \\
\hline 1 & 13.85 & 83.03 & 31.59 & 28 & 0.47 & 1 \\
\hline 2 & 53.92 & 109.51 & 87.75 & 51.87 & 1.15 & 3 \\
\hline 3 & 32.71 & 220 & 188.52 & 151.52 & 0.62 & 2 \\
\hline 4 & 40.03 & 96.93 & 88.06 & 13.68 & 0.51 & 2 \\
\hline 5 & 189.43 & 225 & 192.83 & 76 & 1.43 & 3 \\
\hline 6 & 32.02 & 244.97 & 210.47 & 153.14 & 0.43 & 1 \\
\hline 7 & 100.92 & 317.52 & 249.01 & 156.41 & 0.80 & 2 \\
\hline 8 & 32.62 & 401.68 & 425.03 & 310.68 & 0.32 & 1 \\
\hline 9 & 31.29 & 455.72 & 442.2 & 352.25 & 0.32 & 1 \\
\hline 10 & 171.48 & 510.22 & 473.39 & 388.97 & 1.67 & 3 \\
\hline 11 & 30.11 & 554.82 & 542.74 & 462.85 & 0.35 & 1 \\
\hline 12 & 34.99 & 574.89 & 536.41 & 463.7 & 0.38 & 1 \\
\hline 13 & 28.5 & 651.45 & 638.42 & 550.09 & 0.30 & 1 \\
\hline 14 & 26.34 & 763.63 & 731.08 & 677.11 & 0.37 & 1 \\
\hline 15 & 20.98 & 900.13 & 906.84 & 779.27 & 0.17 & 1 \\
\hline 16 & 48.59 & 1040.38 & 1116.23 & 987.26 & 0.53 & 2 \\
\hline 17 & 56.44 & 1250.07 & 1232 & 1190.19 & 1.11 & 3 \\
\hline 18 & 42.35 & 1437.63 & 1438.59 & 1320.85 & 0.36 & 1 \\
\hline 19 & 47.18 & 1114.98 & 995.12 & 923.54 & 0.36 & 1 \\
\hline 20 & 38.24 & 1184.89 & 1193.86 & 1138.83 & 0.76 & 2 \\
\hline 21 & 42.15 & 1409.17 & 1354.58 & 1266.93 & 0.37 & 1 \\
\hline & 54.41 & 214.39 & 206.39 & 117.83 & 0.59 & 2 \\
\hline 23 & 76.78 & 272.91 & 305.75 & 251.64 & 2.04 & 3 \\
\hline 24 & 20.79 & 327.27 & 307.45 & 294.38 & 0.90 & 2 \\
\hline 25 & 23.79 & 505.2 & 458.77 & 452.76 & 0.81 & 2 \\
\hline 26 & 20.69 & 545.07 & 527.58 & 518.73 & 1.18 & 3 \\
\hline 27 & 24.67 & 441.56 & 438.22 & 382.54 & 0.43 & 1 \\
\hline 28 & 89.64 & 427.02 & 514.69 & 343.89 & 0.71 & 2 \\
\hline 29 & 13.43 & 582.07 & 588.97 & 575.97 & 1.41 & 3 \\
\hline 30 & 35.15 & 458.66 & 502.38 & 408.18 & 0.49 & 1 \\
\hline 31 & 34.04 & 664.302 & 673.32 & 630.11 & 0.88 & 2 \\
\hline 32 & 41.26 & 767.73 & 815.85 & 732.9 & 0.70 & 2 \\
\hline 33 & 25.2 & 446.48 & 508.2 & 417.44 & 0.42 & 1 \\
\hline
\end{tabular}

*Tc: Tectonic Class

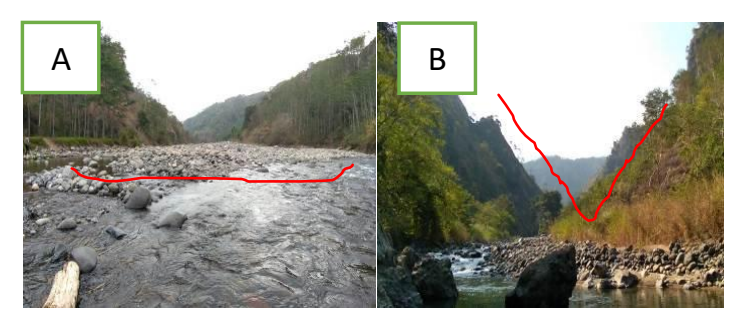

Fig 5: (A) U-shaped valley in the downstream area of the Cilayu watershed (B) V-shaped valley in the upper Cilayu watershed.

\subsection{The Mountain-front Sinuosity Index (Smf)}

The values of $\operatorname{Smf}$ for the study area shown in Table 5. Based on the results of calculations on 17 
ISSN-2347-9698

Volume 8 Issue 7 July 2020

mountain-fronts, the Smf value in the study area varies-form low of 1.16 to a high of 2.54.

Based on the [22] classification, $10 \mathrm{Smf}$ values included in class 1 (active tectonic class), and 7 Smf values included in class 2 (medium to weak tectonic classes). The index of active tectonics (IAT) values obtained after the Smfvalues are grouped based on the classification from [13]. 8 Smf values included in class 2 (moderate) and 9 Smf values included in class 3 (low) (Table 5).

Table 5. Mountain-front Sinuosity Index (Smf) Calculation

\begin{tabular}{|c|c|c|c|c|}
\hline No. & $\begin{array}{c}\boldsymbol{L m f} \\
(\boldsymbol{K} \boldsymbol{m})\end{array}$ & $\boldsymbol{L} \boldsymbol{( K \boldsymbol { m } )}$ & $\boldsymbol{S} \boldsymbol{m f}$ & $\boldsymbol{T} \boldsymbol{c}^{*}$ \\
\hline 1 & 3.29 & 2.61 & 1.26 & 2 \\
\hline 2 & 1.63 & 1.41 & 1.16 & 2 \\
\hline 3 & 2.76 & 2.02 & 1.37 & 2 \\
\hline 4 & 7.25 & 3.51 & 2.07 & 3 \\
\hline 5 & 3.76 & 2.15 & 1.75 & 3 \\
\hline 6 & 2.54 & 1.73 & 1.47 & 2 \\
\hline 7 & 2.01 & 1.53 & 1.31 & 2 \\
\hline 8 & 2.15 & 1.40 & 1.54 & 3 \\
\hline 9 & 1.76 & 1.39 & 1.27 & 2 \\
\hline 10 & 2.25 & 1.85 & 1.22 & 2 \\
\hline 11 & 5.33 & 2.57 & 2.07 & 3 \\
\hline 12 & 2.98 & 1.47 & 2.03 & 3 \\
\hline 13 & 3.94 & 2.17 & 1.82 & 3 \\
\hline 14 & 3.02 & 1.47 & 2.05 & 3 \\
\hline 15 & 2.16 & 1.69 & 1.28 & 2 \\
\hline 16 & 3.28 & 1.29 & 2.54 & 3 \\
\hline 17 & 1.59 & 0.85 & 1.87 & 3 \\
\hline
\end{tabular}

*Tc: Tectonic Class

\subsection{The Hypsometry Integral (Hi)}

The hypsometry curve [19] is a comparison between the difference in relative height and relative area of a watershed. The total area (A) is the total horizontal surface area of the watershed. In comparison, the area value (a) is the surface area of a watershed bounded by a datum contour (specific elevation $\mathrm{h}$ ).

$\mathrm{H}$ is the significant difference between the highest and lowest points of the watershed. The value of relative area $(\mathrm{a} / \mathrm{A})$ is always one at the lowest point of the watershed and the relatively high value $(\mathrm{h} / \mathrm{H})$ $=0$. Moreover, the value of $\mathrm{a} / \mathrm{A}$ is always 0 at the value of $\mathrm{h} / \mathrm{H}=1$.

The hypsometry calculation reflects its lithology resistance influences the erosion status of an area. So it can also be used to identify lithology differences in a watershed.

$H i$, values in the study area calculated at 33 Subwatersheds. Based on the calculation, the $H i$ value of the study area ranged from 0.31 (Sub-watershed 12) to 0.61 (Sub-watershed 3) (Tabel 6).
Table 6. Hipsometry Integral $(\mathrm{Hi})$ Calculation

\begin{tabular}{|c|c|c|}
\hline $\begin{array}{c}\text { Sub- } \\
\text { Watershed }\end{array}$ & $\begin{array}{c}\text { Hypsometry } \\
\text { Integral }(\mathrm{Hi})\end{array}$ & $\begin{array}{c}\text { Tectonic } \\
\text { Class }\end{array}$ \\
\hline 1 & 0.41 & 2 \\
\hline 2 & 0.56 & 1 \\
\hline 3 & 0.61 & 1 \\
\hline 4 & 0.58 & 1 \\
\hline 5 & 0.33 & 3 \\
\hline 6 & 0.48 & 2 \\
\hline 7 & 0.50 & 1 \\
\hline 8 & 0.53 & 1 \\
\hline 9 & 0.51 & 1 \\
\hline 10 & 0.49 & 2 \\
\hline 11 & 0.42 & 2 \\
\hline 12 & 0.31 & 3 \\
\hline 13 & 0.37 & 3 \\
\hline 14 & 0.40 & 2 \\
\hline 15 & 0.52 & 1 \\
\hline 16 & 0.56 & 1 \\
\hline 17 & 0.34 & 3 \\
\hline 18 & 0.46 & 2 \\
\hline 19 & 0.49 & 2 \\
\hline 20 & 0.45 & 2 \\
\hline 21 & 0.58 & 1 \\
\hline 22 & 0.51 & 1 \\
\hline 23 & 0.49 & 2 \\
\hline 24 & 0.43 & 2 \\
\hline 25 & 0.36 & 3 \\
\hline 267 & 0.42 & 2 \\
\hline 27 & 0.56 & 1 \\
\hline 28 & 0.42 & 2 \\
\hline$>\quad 29$ & 0.56 & 1 \\
\hline 30 & 0.50 & 1 \\
\hline 31 & 0.32 & 3 \\
\hline 32 & 0.45 & 2 \\
\hline 33 & 0.51 & 1 \\
\hline
\end{tabular}

From the Hypsometry Integral $\mathrm{Hi}$ ) values in table 6, 7 sub-watersheds have $H i$ values $>0.55$. The range of values, according to [19], is interpreted as youthful (convexity upward curves) where at this stage, an area has begun to experience an erosion process although it is not intensive. Characteristics of areas with youthful stages include the height of the maximum area having a large enough area and having a small area of difference in the area with a lower height.

A total of 10 sub-watersheds have a value of $0.45 \geq$ $H i>0.35$, classified as the mature stage, where this stage occurs a balanced process between the erosion process and the process of removal, denudation, and other tectonic activities. The other 16 sub-watersheds have $H i$ value, which indicates the process of sub-watershed transition from the young to the middle stage and from the middle to the old stage.

According to [13], Hi values in the study area grouped into three classes, namely: Class 1 with a convex hypsometric curve ( $\mathrm{Hi} \geq 0.5)$, Class 2 with 
Volume 8 Issue 7 July 2020

a concave-convex curve $(0.4 \leq \mathrm{Hi}<0.5)$, and Class

3 with concave hypsometric curves $(\mathrm{Hi}<0.4)$.

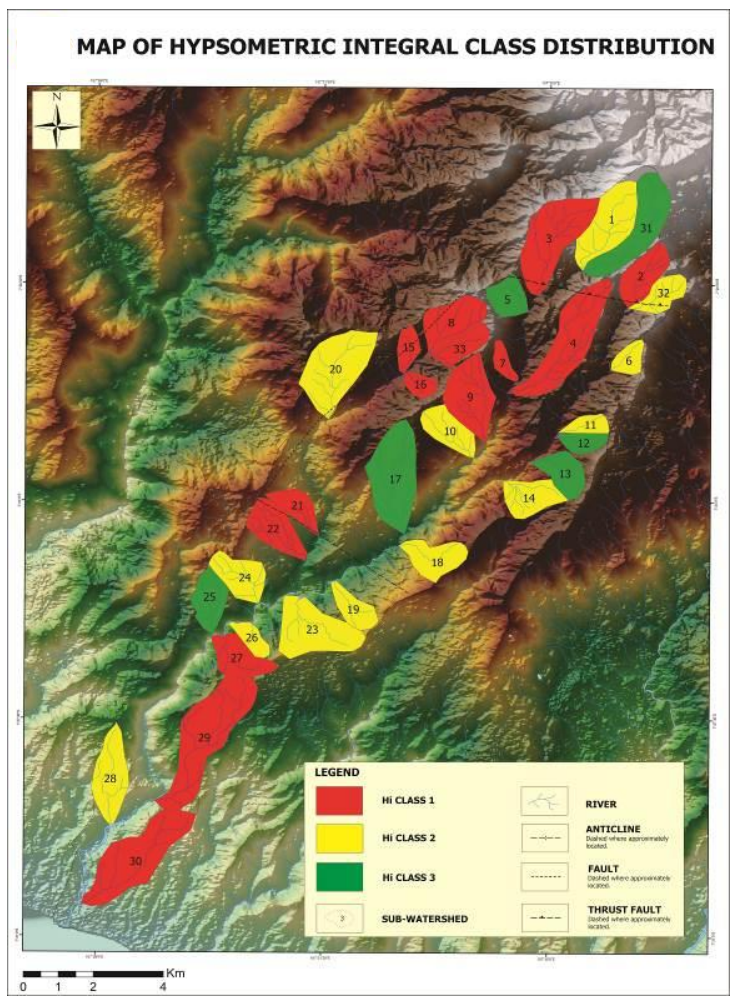

Fig 6:Map that shown the distribution of Hypsometric Integral Values based on classification of [13].

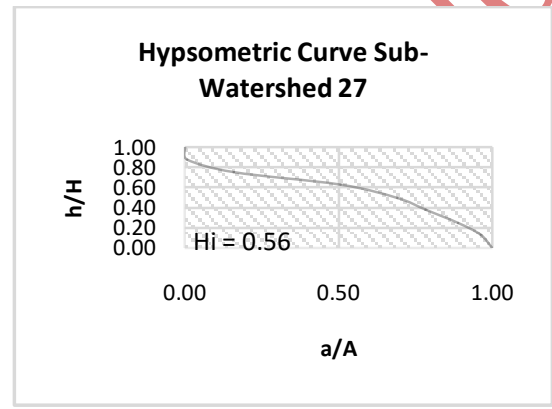

[A]

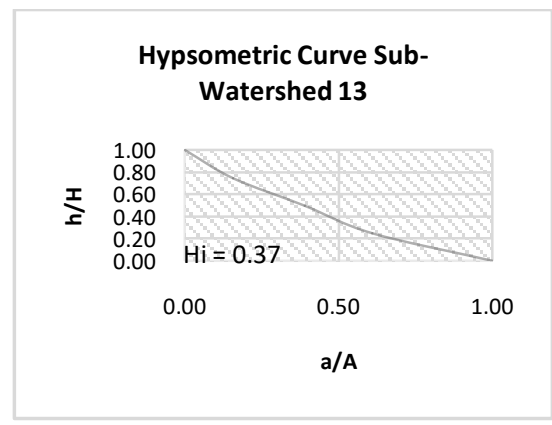

[C]

\subsection{The Index of Active Tectonics (IAT)}

According to [13], IAT is obtained by the average of the different classes of geomorphic indices $(S / n)$ and divided into four classes, where class 1 is a very high tectonic activity with values of $S / n$ between 1 and 1.5; class 2 is a high tectonic activity with values of $S / n>1.5$, but $<2$; class 3 is moderately active tectonics with $S / n>2$ but $<2.5$, and class 4 is low active tectonics with values of $S / n>2.5 . I A T$ values in the research area are divided into four classes: Class 1 (very high), Class 2 (high), Class 3 (moderate), and Class 4 (low). IAT distributions in 33 sub-watersheds covering 119.97 $\mathrm{km}^{2}$ are Class 1 around $1.78 \%$ of the watershed area $\left(2.13 \mathrm{Km}^{2}\right)$, Class 2 around $7.03 \%$ of the watershed area $\left(8.43 \mathrm{Km}^{2}\right)$, Class 3 around $30.61 \%$ of the watershed area $\left(36,81 \mathrm{Km}^{2}\right)$, and Class 4 around $9.69 \%$ of the watershed area $\left(11.62 \mathrm{Km}^{2}\right)$ (Table 7) (Figure 8). It explains that Cilayu Watershed/dominantly has moderate to high tectonic activities.

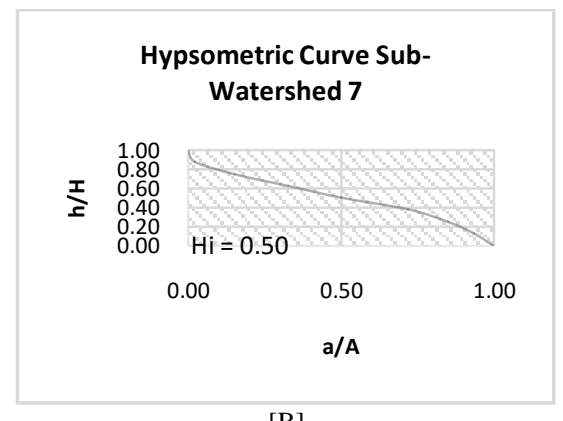

[B]

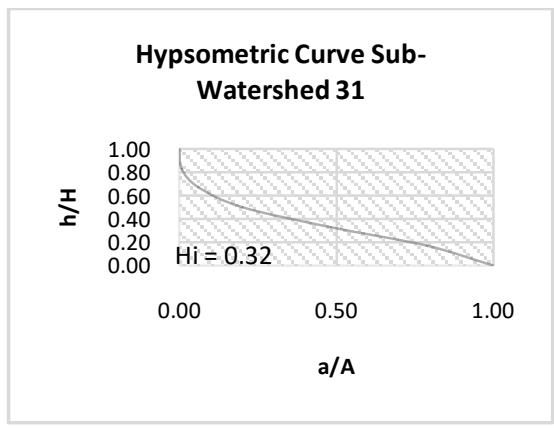

[D] 
Volume 8 Issue 7 July 2020

Fig 7: Representative Hypsometric Curve from selected watershed which shown different stage [A] Youthful (Inequilibrium) stage [B] Transition stage from Youthful (Inequilibrium) to Mature (Equilibrium) stage [C] Mature (Equilibrium) Stage and [D] Transition stage from Mature (Equilibrium) to Monadnock Phase.

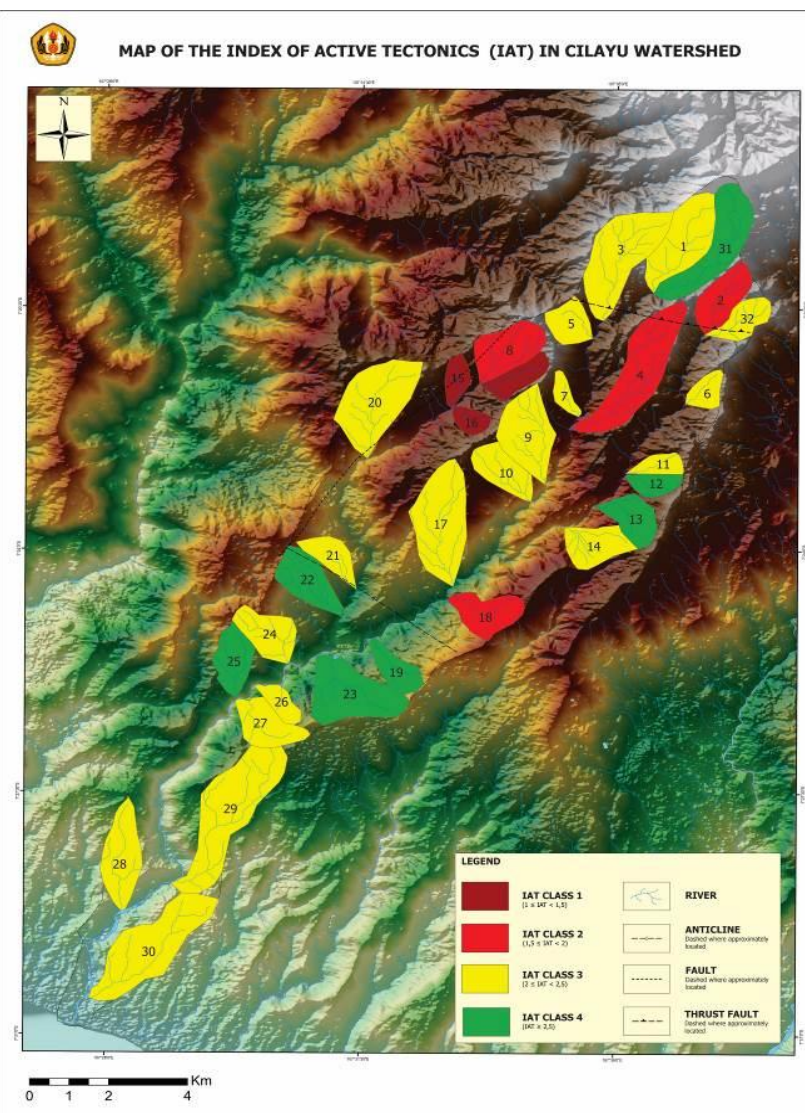

Fig 8: Map that shows the distribution of Index of Active Tectonics (IAT) Values in Cilayu Watershed based on classification of [13].

Table 6. The Index of Active Tectonics (IAT) Calculation

\begin{tabular}{|c|c|c|c|c|c|c|c|}
\hline $\begin{array}{c}\text { Sub- } \\
\text { Watershed }\end{array}$ & $\boldsymbol{A F}$ & $\boldsymbol{B} \boldsymbol{V}$ & $\boldsymbol{V f}$ & $\boldsymbol{S m f}$ & $\boldsymbol{H i}$ & $\boldsymbol{S} / \boldsymbol{n}$ & $\boldsymbol{I A T}$ \\
\hline 1 & 3 & 3 & 1 & 3 & 2 & 2.4 & 3 \\
\hline 2 & 3 & 3 & 2 & 0 & 1 & 1.8 & 2 \\
\hline 3 & 1 & 3 & 2 & 3 & 1 & 2.0 & 3 \\
\hline 4 & 2 & 2 & 1 & 3 & 1 & 1.8 & 2 \\
\hline 5 & 2 & 3 & 1 & 3 & 3 & 2.4 & 3 \\
\hline 6 & 1 & 3 & 2 & 2 & 2 & 2.0 & 3 \\
\hline 7 & 2 & 3 & 2 & 3 & 1 & 2.2 & 3 \\
\hline 8 & 3 & 3 & 2 & 0 & 1 & 1.8 & 2 \\
\hline 9 & 1 & 3 & 2 & 3 & 1 & 2.0 & 3 \\
\hline 10 & 1 & 3 & 1 & 3 & 2 & 2.0 & 3 \\
\hline 11 & 2 & 3 & 2 & 3 & 2 & 2.4 & 3 \\
\hline 12 & 2 & 3 & 2 & 3 & 3 & 2.6 & 4 \\
\hline 13 & 2 & 3 & 2 & 3 & 3 & 2.6 & 4 \\
\hline 14 & 1 & 3 & 2 & 3 & 2 & 2.2 & 3 \\
\hline 15 & 1 & 3 & 2 & 0 & 1 & 1.4 & 1 \\
\hline 16 & 2 & 3 & 1 & 0 & 1 & 1.4 & 1 \\
\hline 17 & 2 & 3 & 1 & 2 & 3 & 2.2 & 3 \\
\hline
\end{tabular}

\begin{tabular}{|l|l|l|l|l|l|l|l|}
\hline 18 & 1 & 3 & 1 & 2 & 2 & 1.8 & 2 \\
\hline 19 & 3 & 3 & 3 & 3 & 2 & 2.8 & 4 \\
\hline 20 & 1 & 3 & 1 & 3 & 2 & 2.0 & 3 \\
\hline 21 & 1 & 3 & 3 & 3 & 1 & 2.2 & 3 \\
\hline 22 & 3 & 3 & 3 & 3 & 1 & 2.6 & 4 \\
\hline 23 & 2 & 3 & 3 & 3 & 2 & 2.6 & 4 \\
\hline 24 & 3 & 3 & 2 & 0 & 2 & 2.0 & 3 \\
\hline 25 & 3 & 3 & 2 & 2 & 3 & 2.6 & 4 \\
\hline 26 & 2 & 3 & 1 & 3 & 2 & 2.2 & 3 \\
\hline 27 & 3 & 3 & 2 & 3 & 1 & 2.4 & 3 \\
\hline 28 & 3 & 2 & 2 & 2 & 2 & 2.2 & 3 \\
\hline 29 & 3 & 2 & 3 & 2 & 1 & 2.2 & 3 \\
\hline 30 & 3 & 2 & 2 & 2 & 1 & 2.0 & 3 \\
\hline 31 & 3 & 3 & 2 & 3 & 3 & 2.8 & 4 \\
\hline 32 & 3 & 3 & 2 & 2 & 2 & 2.4 & 3 \\
\hline 33 & 1 & 3 & 2 & 0 & 1 & 1.4 & 1 \\
\hline
\end{tabular}

\subsection{The Result of Field Observation}

According to [21], the lineament associated with the geological structure could provide information about the tectonic activities. Field observation related to the evidence of the structure through landscape features shown in Fig. 9.
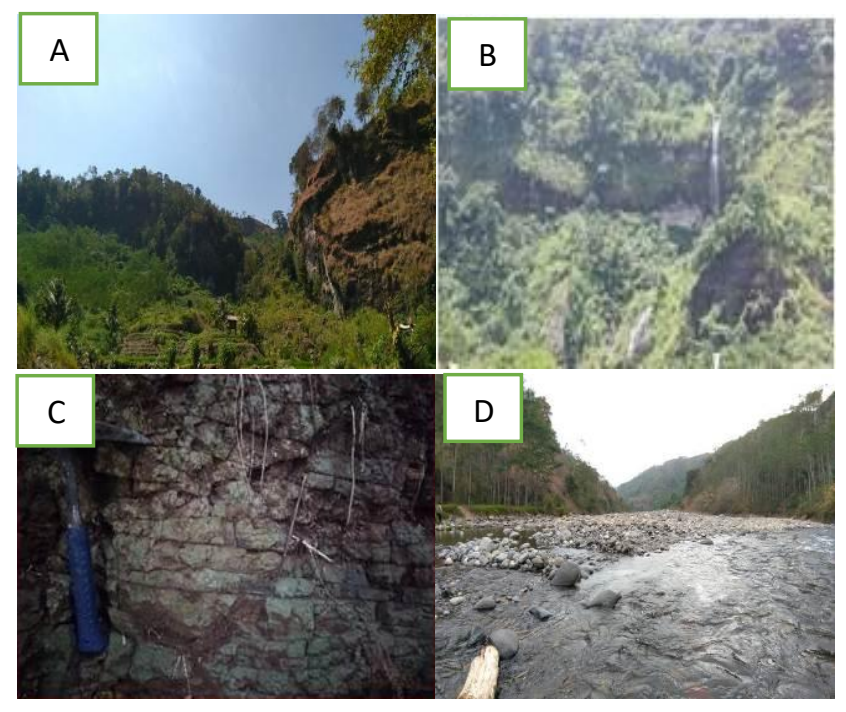

Fig 9: (A) Morphology of Fault Scarp (B) Waterfall (C) Fracture zone (D) Depression zone occupied by alluvial deposits in the southern part of Cilayu watershed. 
Volume 8 Issue 7 July 2020

A.
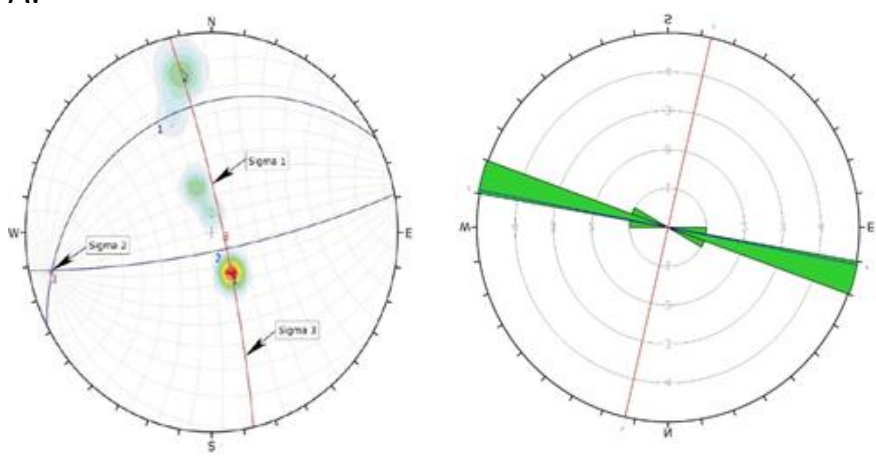

B.

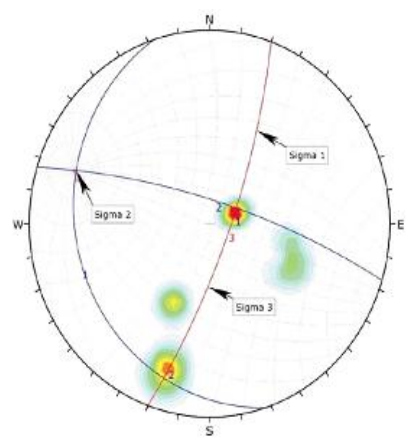

C.

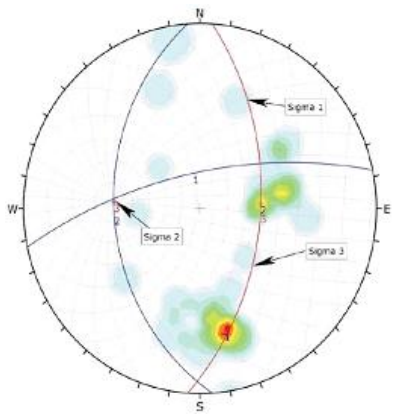

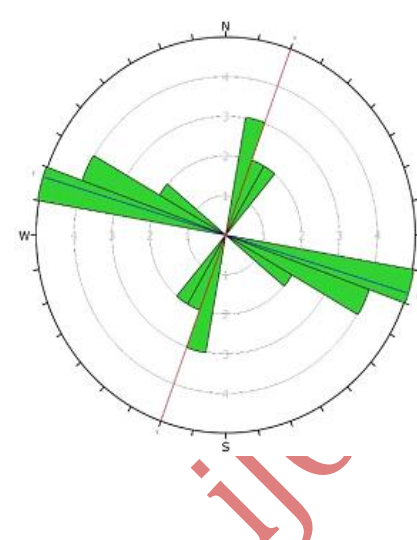

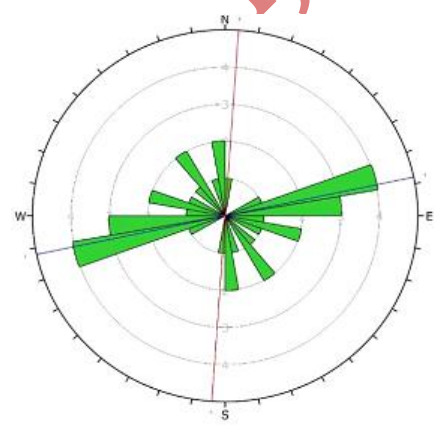

Fig 10: Rosette and Stereonet Diagram from Joint Measurement Analysis (A) OP-17 in Cilayu River (B) OP-E, which located approximately in Rancadarandan and (C) OP-41 which located near Cikoneng.

Joints measurements conducted in several locations of the fracture zone at Cilayu Watershed. Then the result of 'joint' measurement plotted into a rosette and stereonet diagrams. A summary of the site response analysis of the joint measurement shown in Fig. 10.

To simplify the reading of the joint measurement of each observation point result, we used the rosette and stereonet

diagrams. Rosette diagram informs about the fracture trend while the stereonet informs about the trend of the stress, which symbolizes with $\sigma$ (sigma). In this location, the primary fracture trend relative to W-E and the dominant stress trend is $\mathrm{N}-\mathrm{S}$ directions.

Stereonet diagram at OP-17 shows that the dominant tress is sigma $1(\sigma 1)$ with Trend/Plunge of $\mathrm{N} 0^{0} \mathrm{E} / 62^{0}$ indicating a normal fault.Stereonet diagram at OP-E shows that the dominant tress is sigma $3(\sigma 3)$ with Trend/Plunge of $\mathrm{N}$ $180^{\circ} \mathrm{E} / 53^{\circ}$ indicating a thrust fault. Furthermore, the stereonet diagram at OP-41 shows that the dominant tress is sigma $3(\sigma 3)$ with Trend/Plunge of $\mathrm{N} 138^{\circ} / 43^{0}{ }^{\circ}$ indicating a thrust fault.

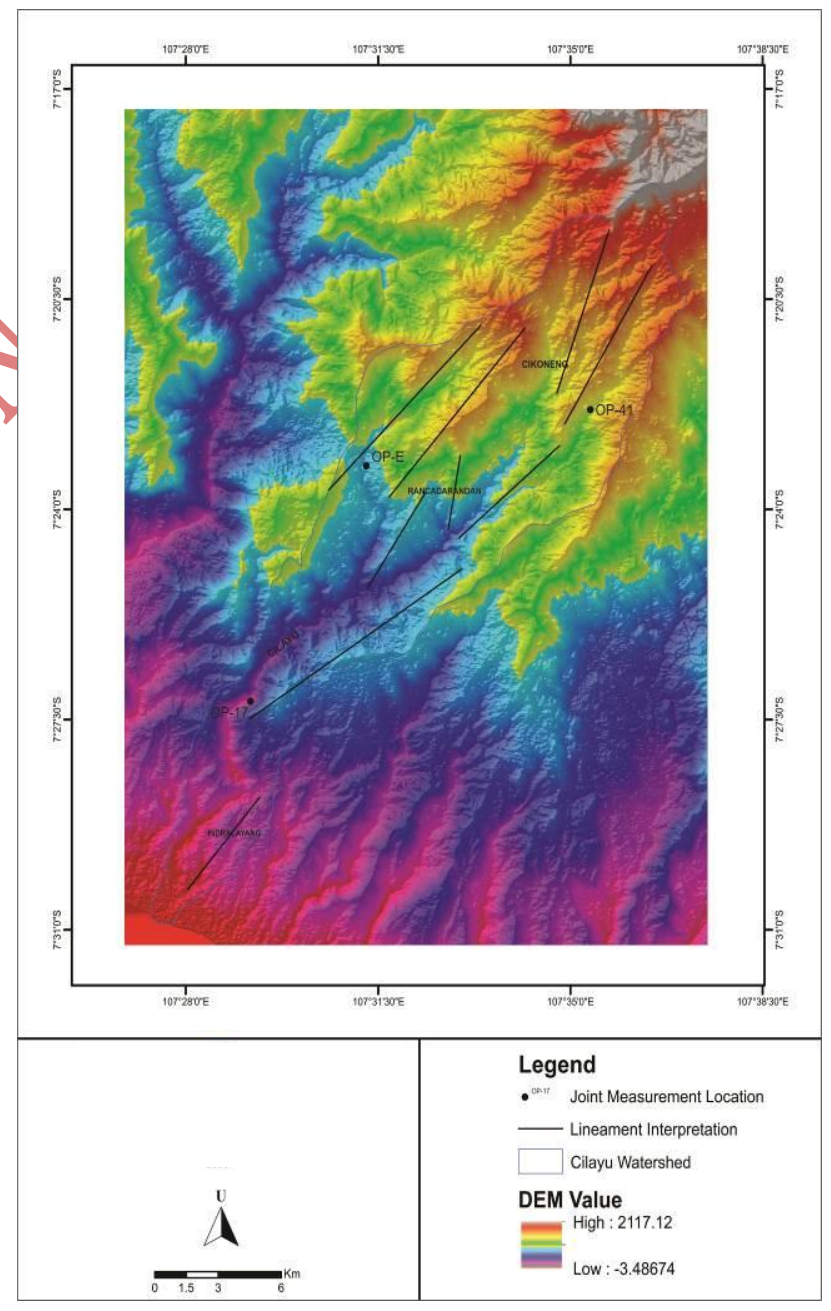

Fig11: Lineament interpretation map of the study area related to the result of plotting joint on the rosette and stereo-net diagrams at OP-17, OP-41, and OP-E, which is shown in Fig. 9 before. They express that development of geological structure in Cilayu Watershed has main trends of faults; NE-SW directions. 
Volume 8 Issue 7 July 2020

\subsection{Discussion}

The calculation result is indicating that the active-tectonic level took place at several parts of the study area. The values of $A f, H i$, and $V f$ found to be high in the northern part of the area. The values of $A f$ show widespread drainage basin asymmetry related to tectonic tilting. Active tectonic conditions in the study area also determined from the mountain-front sinuosity parameter index (Smf). Analysis of the variables Smf also supports a correlation between landscape and tectonic. Smfindex values obtained from the calculation ranged from 1.16 to 2.54 . This phenomenon shows that the case of uplift as an indication of tectonic activity in the watershed Cilayu. The values of $V f$ show that many valleys are narrow and deep, suggesting a high rate of incision associated with tectonic uplift. The Values of $B s$ show that the tectonic process is slowing down, and the erosion process tends to develop more, causing the shape of the watershed to become more rounded.

Therefore those analyses are confirmed by evidence found from fieldwork. The area which is affected by the active tectonic characterized by the presence of fractures in the rock, escarpment fault, ridge and valley lineaments. Morphotectonic characteristics in the Cilayu watershed can be an indication of the effect of active tectonics are as follows:

- The lineament of ridge and valley

- The lineament of drainage pattern

- The extreme curve of the river around Cibaregbeg and Rancadarandan

- Broad depression zones and occupied by alluvial deposits in the southern part of Cilayu watershed.

Furthermore, the Joints at OP-17 show that the dominant tress is sigma 1 (s1) with Trend/Plunge of $\mathrm{N} 0^{0} \mathrm{E} / 62^{0}$ indicating a normal fault.The Joins at OP-E show that the dominant tress is sigma 3 (s3) with Trend/Plunge of $\mathrm{N} 180^{\circ}$ E $/ 53^{0}$ indicating a thrust fault. Furthermore, Joints at OP-41 show that the dominant tress is sigma 3 (s3) with Trend/Plunge of $\mathrm{N} 138^{0} / 43^{0}$,indicating a thrust fault.

It can conclude that Cilayu watershed has an active tectonic activity, which is confirmed by the result of field interpretation and quantitative geomorphic indices assessments. In order to validate the tectonic intensity, this study combines geomorphic indices to derive IAT value.

IAT values in the research area divided into four classes: Class 1 (very high), Class 2 (high), Class 3 (moderate), and Class 4 (low). IAT distributions in 33 sub-watersheds covering $119.97 \mathrm{~km}^{2}$ are Class 1 around $1.78 \%$ of the watershed area $\left(2.13 \mathrm{Km}^{2}\right)$, Class 2 around $7.03 \%$ of the watershed area $\left(8.43 \mathrm{Km}^{2}\right)$, Class 3 around $30.61 \%$ of the watershed area $\left(36,81 \mathrm{Km}^{2}\right)$, and Class 4 around $9.69 \%$ of the watershed area $\left(11.62 \mathrm{Km}^{2}\right.$ ) (Table 7) (Figure 8). It explains that Cilayu Watershed dominantly has moderate to high tectonic activities.

\section{CONCLUSIONS}

The Geomorphic indices computed using GIS considered to be suitable for evaluating the effects of active tectonics over Cilayu Watershed. To assess tectonic activity in the area, we analyzed fives geomorphic indices: the mountain front sinuosity index $(S m f)$, valley floor width-to-height ratio $(V f)$, drainage basin asymmetry factor $(A f)$, drainage basin shape $(B S)$, and hypsometric integral (Hi).

The values of $A f, H i$, and $V f$ found to be high in the northern part of the area. The values of $A f$ show widespread drainage basin asymmetry related to tectonic tilting while the values of Smf suggest that mountain fronts are tectonically active. The values of $V f$ show that many valleys are narrow and deep, suggesting a high rate of incision associated with tectonic uplift. The Values of $B s$ show that the tectonic process is slowing down, and the erosion process tends to develop more, causing the shape of the watershed to become more rounded.

About two-thirds of the Cilayu watershed has Iat values of classes 2 and 3, indicating moderately to highly active tectonics. Class 1 and 2 of Iat, indicative of the most active tectonics, occurs mainly in the northern part of the study area along the fault and fold zone. Class 3 of Iat corresponding to moderately active tectonics occurs over almost the whole study area, while Class 4 of Iat mainly takes place in the center of the study area.

The results confirm the usefulness of geomorphic indices analyses for assessing regional tectonics. They also suggest the necessity of future detailed research about tectonics in the study area. It expected the risk of disaster could minimize if, at any time, the disaster due to tectonic activity happens in the area.

\section{ACKNOWLEDGMENTS}

Our gratitude goes to the leadersof UniversitasPadjadjaranfor their support through the internal research grant of the 2020 RKDU scheme. Hopefully the results of this study will benefit the development of science and society.

\section{REFERENCES}

[1] Molin, P., Pazzaglia, F.J., Dramis, F., "Geomorphic expression of active tectonics in a rapidly-deforming forearc, Sila Massif, Calabria, Southern Italy," American Journal of Science 304, 559-589, 2004.

[2] Dumont, J.F., Santana, E., Vilema, W., "Morphologic evidence of active motionof the Zambapala Fault, Gulf of Guayaquil (Ecuador)," Geomorphology 65, 223-239, 2005. 
Volume 8 Issue 7 July 2020

[3] Necea, D., Fielitz, W., Matenco, L., "Late PlioceneQuaternary tectonics in the frontal part of the SE Carpathians: insights from tectonic geomorphology," Tectonophysics410, 137-156, 2005.

[4] Seeber, L., Gornitz, V., "River profiles along the Himalayan Arc as indicators ofactive tectonics," Tectonophysics 92, 335-367, 1983.

[5] Brookfield, M.E., "The evolution of the great river systems of southern Asia during the Cenozoic IndiaAsia collision: rivers draining southwards," Geomorphology 22,285-312, 1998.

[6] Chen, Y.C., Sung, Q.C., Cheng, K.Y., “Along-strike variations of morphotectonic features in the Western Foothills of Taiwan: tectonic implications based onstream-gradient and hypsometric analysis," Geomorphology 56, 109-137, 2003.

[7] Keller, E.A., Pinter, N., Active Tectonics: Earthquakes, Uplift, and Landscape.Prentice-Hall, New Jersey, 2002.

[8] Kobor, J.S., Roering, J.J., "Systematic variation of bedrock channel gradients in the central Oregon Coast Range: implications for rock uplift and shallow landsliding," Geomorphology 62, 239-256, 2004.

[9] E. Sukiyah, I. Syafri, A. Sjafrudin, E. Nurfadli, P. Khaerani, and D.A.P. Simanjuntak, "Morphotectonic and satellite imagery analysis for identifying quaternary fault at the southern part of CianjurGarutregion, West Java, Indonesia," in Proc. Asian Conference on RemoteSensing, 2015, pp. 1-10.

[10] Koesmono, K., Kusnama, \&Suwarna, N., "Geological Map of Sindangbarang and Bandarwaru Sheet, Scale 1:100,000," 2nd edition, Geological survey Centre, Geology Agency, Bandung, 1996.

[11] Alzwar M., Akbar N., \&Bachri S., "Geological Map of Garut and Pameungpeuk sheet, Jawa, Scale 1: 100,000," 2nd edition,Geological survey Centre, Geology Agency, Bandung, 1992

[12] Hare, P.W., Gardner, T.W., "Geomorphic indicators of vertical neotectonic along converging plate margins, Nicoya Peninsula, Costa Rica," In Morisawa, M., Hack, J.T. (Eds.), Tectonic Geomorphology. Proceedings of the 15th Annual BinghamtonGeomorphology Symposium. Allen and Unwin, Boston, pp. 123-134, 1985.
[13] El Hamdouni, R., Irigaray, C., Fernandez, T., Chacón, J., Keller, E.A., "Assessment of relative active tectonics, southwest border of Sierra Nevada (southern Spain),"Geomorphology 96, 150-173, 2007.

[14] J.V. Pérez-Peña, A. Azor, J.M. Azañón, and E.A. Keller, "Active tectonics in the Sierra Nevada (Betic Cordillera, SE Spain): Insights from geomorphic indexes and drainage pattern analysis,"Geomorphology, vol. 119, pp. 74-87, June 2010.

[15] M. Dehbozorgi, M. Pourkermani, M. Arian, A.A. Matkan, H. Motamedi, and A. Hosseiniasl, "Quantitative analysis of the relative tectonic activity in the Sarvestan area, central Zagros, Iran," Geomorphology 121, 2010.

[16] Bull, W.B., Tectonic Geomorphology of Mountains: A New Approach to Paleoseismology. Wiley-Blackwell, Oxford, 2007.

[17] Ramírez-Herrera, M.T., "Geomorphic assessment of active tectonics in the Acambay Graben, Mexican volcanic belt," Earth Surface Processes and Landforms 23, 317-332, 1998.

[18] Bull, W.B., McFadden, L., "Tectonic geomorphology north and south of the Garlock Fault, California. In: Doering, D.O. (Ed.), Geomorphology in Arid Regions," StateUniversity of New York, Binghamton, pp. 115-138, 1977.

[19] Strahler, A.N., "Hypsometric (area-altitude) analysis of erosional topography," Geological Society of America Bulletin 63, 1117-1142, 1952.

[20] Silva, P.G., Goy, J.L., Zazo, C., Bardaji, T., "Faultgenerated mountain fronts in southeast Spain: geomorphologic assessment of tectonic and seismic activity," Geomorphology50, 203-225, 2003.

[21] E. Sukiyah, I. Syafri, B.J. Winarto, B. Susilo, A. Saputra, and E. Nurfadli, "Active faults and their implications for regional development in the southern part of West Java, Indonesia," in Proc. The 24th annual scientific conference \& exhibitions, Federation International Surveyors, pp. 1-12, 2016.

[22] Doornkamp, J. C. "Geomorphological Approaches to the Study of Neotectonics," Journal of Geological Society, Vol. 143: 335-342, 1986. 